\title{
The Influence of Fermented Feed to the Exterior and Interior Quality of Pegagan Duck Eggs
}

\author{
Sofia Sandi, Miksusanti, Eli Sahara, and Fitri Nova Liya Lubis
}

\begin{abstract}
The aims of this research was to find out the influence of complete feed based on fermented local ingredients to the exterior and interior quality of pegagan duck eggs. Complete feed based on fermented local ingredients (C.F.B.F.L) with commercial feed was mixed every weeks in accordance with the level of treatment. Feeds were arranged with protein content $(18 \%)$ and metabolism energy $(2900$ $\mathrm{kcal} / \mathbf{k g}$ ) in accordance with recommendations of NRC. As many as sixty pegagan duck aged 4 months were used in the study. Completely random design was used in this research, with 5 treatments and 4 replicates. Each of these repeats were placed 3 ducks and kept for 3 months. The treatment consisted of R0 (100\% commercial feed), R1 (25\% C.F.B.F.L + $75 \%$ commercial feed), R3 (50\% C.F.B.F.L + 50\% commercial feed), R4 (75\% C.F.B.F.L $+25 \%$ commercial feed), R5 (100\% C.F.B.F.L). The results showed that the giving of complete feed based on fermented local ingredients effected the value of egg index, yolk egg score, thickness of eggshell, and wholeness and cleanliness of eggs. It was concluded that the increasing level of giving complete feed based on fermented local ingredients, the higher value of egg index and yolk egg score, but the thickness of eggshell was getting lower.
\end{abstract}

Index Terms-Exterior and interior eggs quality, local ingredients, Pegagan duck.

\section{INTRODUCTION}

Eggs derived from pegagan ducks were an alternative local resources that need to be developed. Factors that affect the quality of the eggs is the quality of feed and most commercial feed for livestock ducks are circulating in Indonesia contain antibiotics such as a mixture of fish flour for cake, soy, corn, wheat by products/polar, and some are feed such as minerals and vitamins that are alleged to contain cattle products strong antibiotic residues [1].

According to The Directorate General of Animal Husbandry [2] that the use of antibiotics in animal feed in 2007 amounted to 502.27 tons, then was increasing in 2009 to be 5.574 .16 tons. Antibiotic usage over 500 grams/ton feed residues produced in the flesh [3]. It causes resistance of pathogenic microorganisms in the body for human consumption [4]. For the use of alternative raw materials local feed needs to be optimally, since it contains natural micro-containing phytonutrien (such as polyphenols and carotenoids) that have a functional activity as imunomodulator immunity. According to [5], to make

Manuscript received Januray 10, 2013; revised March 11, 2013.

Sofia Sandi, Eli Sahara, and Fitri Nova Liya Lubis are with Depatment of Animal Science, Faculty of Agriculture, University of Sriwijaya (e-mail: sofiasandi_nasir@yahoo.com).

Miksusanti is with Department of Chemistry, Faculty of Mathematics and Natural Sciences, University of Sriwijaya. quality egg is very dependent on natural feed given to note the enhanced feed raw material quality.

The source of the raw material of the local feed quite a lot available in South Sumatra is a by-product of agriculture, forestry, market and households as well as the results of the followup of agro-industries, however the quality of the feed materials low nutrients especially rude protein content is low, and grainy high fiber. However, through the process of fermentation is processing the matter could be resolved so that the utilization of raw materials based on local raw materials can be optimized as cattle ration ducks pegagan especially in getting a quality organic eggs. Based on the above research needs to be done the influence of complete feed based on fermented local ingredients to exterior and interior egg quality of pegagan ducks.

\section{MATERIALS AND METHODS}

\section{A. Animals and Experimental Design}

Ducks used in the study was females pegagan ducks aged 4 months as many as 60 ducks. Ducks were obtained from Sungai Pinang village, Ogan Ilir Regency, South Sumatra, Indonesia.

Type of enclosure that is used for maintenance is multilevel cage as many as 60 cages. Each cage was filled one female pegagan duck. Lighting and heating home using incandescence 40 watts. At any enclosure furnished again with place eating and drinking. Other equipment used is scales to weigh ducks, feed and rest feed

\section{B. Feeds}

Control feed used in the study is a commercial feed that consists of a mixture of some of the material feed, such as corn, soy, rice bran, coconut for cake, fish meal, vegetable oil and animal feed premix, whereas treatment is a complete feed is fermented using EM-4 which consists of the bran, corn, tofu dregs, hyacinth, kernel oil, cassava leaves, snails gold and grit. The feed is structured with a protein content of $16 \%$ and metabolic energy of $2900 \mathrm{kcal} / \mathrm{kg}$, based on recommendations of the NRC [6].

\section{Feed Processing}

Preparation of inokulum in $100 \mathrm{ml}$ of the solution is the EM-4 $7.5 \mathrm{ml}$ and solution of molases $7.5 \mathrm{ml}$ plus $80 \mathrm{ml}$ of water. Mix the solution (kept for 24 hours) is inokulum. The process of fermentation of the feed is done by adding inokulum on the feed (bran, corn, tofu dregs, hyacinth, kernel oil, cassava leaves, snails gold and grit) with a moisture content of $60 \%$. Mixed feed and inokulum closed tightly in a plastic bag and placed, sheltered from direct sunlight. 
TABLE I: FEED COMPOSITION USED IN RESEARCH

\begin{tabular}{llllll}
\hline Parameters & \multicolumn{5}{c}{ Treatments } \\
\hline $\begin{array}{l}\text { Dry matters } \\
\text { (\%) }\end{array}$ & R0 & R1 & R2 & R3 & R4 \\
Ash (\%) & 92.03 & 90.15 & 91.83 & 92.52 \\
$\begin{array}{l}\text { Crude Lipid } \\
(\%)\end{array}$ & 20.64 & 22.14 & 18.83 & 21.50 & 19.27 \\
\hline
\end{tabular}

\begin{tabular}{llllll}
\hline $\begin{array}{l}\text { Crude } \\
\text { Protein (\%) }\end{array}$ & 17,03 & 18.84 & 18.75 & 18.41 & 18.97 \\
$\begin{array}{l}\text { Crude Fiber } \\
\text { (\%) }\end{array}$ & 10,81 & 11.60 & 11.89 & 11.23 & 11.55 \\
$\mathrm{Ca}(\%)$ & 1,23 & 0.91 & 0.95 & 0.87 & 0.81 \\
$\mathrm{P}(\%)$ & 1.69 & 1.34 & 1.27 & 1.03 & 0,96 \\
$\mathrm{GE}(\mathrm{kkal} /$ & 3528.75 & 3574.40 & 3846.31 & 3658.37 & 3810.35 \\
$\mathrm{~kg})$ & & & & & \\
\hline
\end{tabular}

The fermentation process is done for 4 days, then conducted under the dryer aërated. Mixing of complete feed based on fermented local raw materials with feed commercial conducted was done each week in accordance with the level of treatment. Feed composition used in this research shows on Table I.

\section{Testing of Egg Quality}

Sampling procedures were began after the egg-laying duck smoothly beginning 8 weeks of production given feed appropriate treatment. Egg sampling was done randomly in accordance with treatment that is collected for 1 week. Design used in this study was a completely random design with 5 treatments and four replicates. The treatment consists of: R0 (100\% commercial feed), R1 (25\% C.F.B.F.L + 75\% commercial feed), R2 (50\% C.F.B.F.L + 50\% commercial feed), R3 (75\% C.F.B.F.L + 25\% commercial feed), R4 (100\% C.F.B.F.L).

Parameters observed were exterior egg quality, included integrity, hygiene, egg shape and index. Interior egg quality, included yolk egg score (using Yolk Colour Fan) [7], eggshell thickness (using micrometer caliper), and Haugh Unit [8].

\section{E. Statistical Analysis}

Data were analyzed with ANOVA using SAS 6.12, and if it shows significantly difference followed by Duncan Multiple Range Test [9].

\section{RESUlTS AND DISCUSSION}

\section{A. Exterior Quality of Egg}

Exterior quality of the egg is the quality of outer egg part, which included wholeness, cleanliness of egg shall, egg shape, and egg index (comparison between width and length of the egg).

The exterior quality of the egg during research shown in Table II.

The results of observation of the wholeness and cleanliness of egg showed that $90 \%$ of the egg shell cracked or not intact, clean from dirt and stains of blood that stuck to the egg shell. Romanoff and Romanoff [10] reported that the quality of the exterior of the egg is good and deserves to be consumed is intact and clean and free of dirt which stuck on eggshell. While the shape of the egg of observation during the study showed results $100 \%$ of the oval. It indicates that the quality of the eggs is included in A quality because according to the Directorate General of Animal Husbandry [2] which included A quality and is consumed when seen in its unique egg shape is having a somewhat squashed into the middle or oval.

TABLE II: THE EXTERIOR QuALITy OF PEGAGAN DUCK EGG DURING RESEARCH

\begin{tabular}{|c|c|c|c|c|c|}
\hline \multicolumn{6}{|c|}{ RESEARCH } \\
\hline \multirow[t]{2}{*}{ Parameters } & \multicolumn{5}{|c|}{ Treatments } \\
\hline & R0 & $\mathrm{R} 1$ & $\mathrm{R} 2$ & $\mathrm{R} 3$ & $\mathrm{R} 4$ \\
\hline wholeness & whole & whole & whole & whole & whole \\
\hline cleanliness & clean & clean & clean & clean & clean \\
\hline shape & oval & oval & oval & oval & oval \\
\hline Egg & $74.62^{c}$ & $79.84^{\mathrm{ab}}$ & $80.46^{\mathrm{a}}$ & $76.94^{\mathrm{bc}}$ & $81.06^{\mathrm{a}}$ \\
\hline index $(\%)$ & \pm 10.21 & \pm 12.53 & \pm 6.23 & \pm 8.45 & \pm 15.43 \\
\hline \multicolumn{6}{|c|}{$\begin{array}{l}\text { Note : R0 (100\% commercial feed), R1 }(25 \% \text { C.F.B.F.L }+75 \% \\
\text { commercial feed), R2 }(50 \% \text { C.F.B.F.L }+50 \% \text { commercial feed }), R 3(75 \% \\
\text { C.F.B.F.L }+25 \% \text { commercial feed }), \text { R4 }(100 \% \text { C.F.B.F.L }) . \text { Different } \\
\text { superscript means that the results is significantly different }(P>0,05) .\end{array}$} \\
\hline
\end{tabular}

The results of analysis shown that the giving of complete feed based on fermented local ingredients significantly effect $(\mathrm{P}>0.05)$ on eggs index of pegagan duck. Egg index on R4 (100\% C.F.B.F.L), R2 (50\% C.F.B.F.L + 50\% commercial feed), R1(25\% C.F.B.F.L $+75 \%$ commercial feed) significantly difference with R0 (100\% commercial feed) and R3 (75\% C.F.B.F.L + 25\% commercial rations). Increasing the level of feeding complete fermentation based on local ingredients, then increasing eggs index of pegagan duck when compared with control rations (commercial ration). Willson [11] reported that the shape of the egg is the expression of protein feed. Protein feed will affect the viscosity of eggs and identifying the quality of the exterior of the egg, than affects the egg index. The range of egg index during the study was 74.62-81.06\%. Egg index obtained is still in the normal range.

Romanoff [10] that the best egg index is 74\%. Explained further that factors affecting egg index is the production status, genetic variation, individuals or groups. Observations Srigandono [12] states that the normal index of duck eggs ranged from $61.30 \%$ to $81.70 \%$.

\section{B. Interior Egg Quality}

The interior quality of eggs is the egg quality on the inside which includes a score of egg yolks, eggshells thickness, the value of Haugt units (HU). Egg interior quality observed during research shown in Table III.

TABLE III: THE INTERIOR QUALITY OF PEGAGAN DUCK EGGS DURING

\begin{tabular}{lccccc}
\multicolumn{5}{c}{ RESEARCH } \\
\hline Parameters & R0 & R1 & R2 & R3 & R4 \\
\hline Egg yolk & 9 & 11 & 11 & 12 & 14 \\
score & & & & & \\
$\begin{array}{l}\text { Eggshell } \\
\text { thickness } \\
\text { (mm) }\end{array}$ & $0.35^{\mathrm{a}}$ & $0.29^{\mathrm{b}}$ & $0.28^{\mathrm{b}}$ & $0.26^{\mathrm{b}}$ & $0.26^{\mathrm{b}}$ \\
$\begin{array}{l}\text { Haugt } \\
\text { Unit(HU) }\end{array}$ & 60,003 & $\pm 0,002$ & $\pm 0,006$ & $\pm 0,001$ & $\pm 0,001$ \\
\hline
\end{tabular}

Note : R0 (100\% commercial feed), R1 (25\% C.F.B.F.L + 75\% commercial feed), R2 (50\% C.F.B.F.L + 50\% commercial feed), R3 (75\% C.F.B.F.L $+25 \%$ commercial feed), R4 (100\% C.F.B.F.L). Different superscript means that the results is significantly different $(\mathrm{P}>0,05)$.

Yolk egg color during research show that score the yolk has increased along with the increasing level of giving 
complete feed based on fermented local ingredients compared with controls feed (Fig. 1). the smallest score of egg yolk color lies in the treatment of the R0 $(100 \%$ commercial feed), which is 9 , whereas the highest score lies in the treatment of the R4 (100\% C.F.B.F.L), which is 14 .

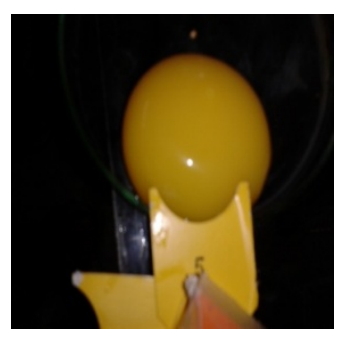

a

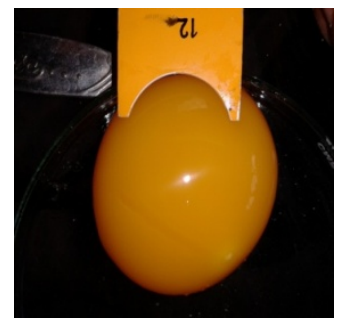

C

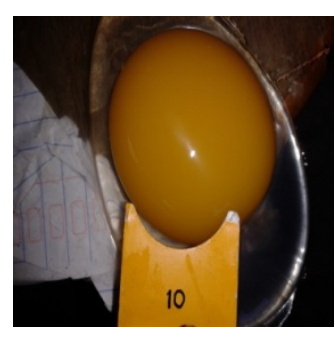

b

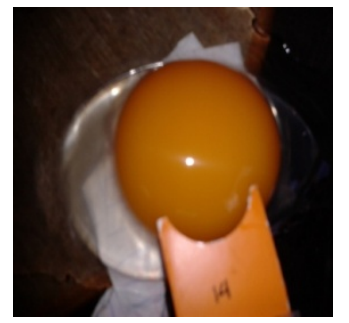

d
Fig. 1. The yolk color of pegagan duck egg. (a) R0 (100\% commercial feed), (b) R1 (25\% C.F.B.F.L + 75\% commercial feed), (c) R2 (50\% C.F.B.F.L $+50 \%$ commercial feed), (d) R4 (100\% C.F.B.F.L).

It is suspected because of the fermented local raw materials contain pigment that gives color to egg yolks, such as water hyacinth leaves, cassava leaves and gondang/gold snail. One of the pigments that make up the color of egg yolks is b-carotene which amounted to $0.02 \%$ of the total weight of dried egg [13]. The results showed that increasing level of feeding complete fermentation-based local, increasing content of b-carotene. b-carotene is the karatenoid who serves as the pigment in addition to antioxidants and vitamin A prekusor [10] The addition of xantophyl contained on local raw materials to the feed can increase the egg yolk color score [14]. According to Sinaga [15], the addition of cassava and kalindra leaves can increase intensity of Cirebon duck yolk eggs color.

The results of the analysis showed that the giving of complete feed based on fermented local ingredient significantly effected $(\mathrm{P}>0.05)$ thickness of pegagan duck eggshell. This indicates that increasing level of giving the complete feed fermentation based on local ingredients will be progressively lowered the eggshells thickness compared to the giving of control feed (commercial feed). the thickness of the egg shells on the R1, R2, R3 and R4 differ significantly with R0. Eggshell thickness is highest on the R0 treatment (100\% commercial feed) which is $0.35 \mathrm{~mm}$, and the lowest at the R4 treatment $(100 \%$ C.F.B.F.L $)$ that is $0.26 \mathrm{~mm}$. it is influenced by the mineral content in feed especially calcium and phosphorus, where the higher feeding levels-local, then the lower the content of calcium and phosphorus in animal feed. According to Romanoff and Romanoff [10], eggshells composed of calcium carbonate, and a bit of sodium, potassium and magnesium and phospor. Thickness of eggshell from the research relative less normal because according to Romanoff and Romanoff [10], thickness of duck eggshells that normally ranges from 0.3 -
$0.5 \mathrm{~mm}$. next Roesdiyanto [16], thickness of local duck eggshells ranging between $0.32-0.36 \mathrm{~mm}$.

The results of analysis show that the giving of complete feed fermentation based on local raw materials do not significantly effected $(\mathrm{P}>0.05)$ on Haugt units. This indicates that increasing the level of giving complete feed fermentation based on local produced Haugh units value is the same as feeding control (commercial feed). But there is a tendency that increasing the level of giving the complete feed fermentation based on local, increasing the value of Haugh Unit. Highest value of Haugt unit in treatment R3 (75\% C.F.B.F.L $+25 \%$ commericial feed), which is 68.79 , while the lowest in treatment R0 (100\% commercial feed), which is 64.08. HU value obtained from different this research was not significantly different. It was because the statistical analyses shown that eggs weights and egg white weights were not significantly different. Stadelman and cotterill [17] stated that the higher or thicker white of eggs, the higher Haugh Unit (HU) value. The range of HU value in research is 64.08-68.79. According to standard issued by USDA that is, the HU value of 72 or more including the AA quality (best), 60-72 including the A quality (good), 31-60 including the B quality (average), less than 31 including the Cquality (less) [8], then the eggs which is produced from this research in any treatment have good qualities.

\section{CONCLUSION}

The increasing level of giving complete feed based on fermented local ingredients, the higher value of egg index, egg yolk score, and Haugh Unit, but thickness of eggshell is getting declining.

\section{ACKNOWLEDGMENT}

Authors thanks to Sriwijaya University Research Centre that had been given "Unggulan Kompetitif Grant" to conduct this research.

\section{REFERENCES}

[1] S. Bahri, E. Masbulan, and A. Kusumaningsih, "Preproduction process as an important factor in producing safe livestock products for humans," Journal of Agricultural R \& D, vol. 24, no. 1, pp. 27-35, 2005.

[2] The Directorate General of Animal Husbandry, Livestock Statistics Book, The Ministry of Agriculture, Jakarta, Indonesia, pp. 67-70, 2010 .

[3] D. Hermawati, "Residue antibiotics in broiler that was given a dose of the treatment of Spiramisina," M. S. Thesis, Bogor Agricultural University, Bogor, Indonesia, pp. 23-25, 1997.

[4] I. Phillips, M. Casewell, T. Cox, B. Groot, C. Friis, R. Jones, C. Nightingale, R. Preston, and J. Waddell, "Does the use of antibiotics in food animals pose a risk to human health?," Journal of Antimicrobial Chemotherapy, vol. 53, pp. 28-52, 2004.

[5] I. Setiawan. (Februari 2012). Organic eggs. [Online]. Available: http://centralunggas.blogspot.com/2011/02/telurorganik.html\#ixzz19n gpAmfj.

[6] NRC, Nutrien Requirement of Poultry, 9th ed. Washington D.C., USA: Nationa1 Academic Press, pp.54-60, 1994.

[7] P. Hunton, "Laboratoty Evaluations of Egg Quality," Eggs Quality Current Problems and Recent Advances, R.G Wells and C.G Belyavin, Ed., London, Butterwarths, pp. 51-70, 1987.

[8] G. J. Mountney, Poultry Product Technology, 2nd ed.. Westport. Connecticut: The AVI Publishing Campany. Inc, pp.89-121, 1978.

[9] R. G. D. Steel and J. H. Torrie, Statistical Procedures and Principle, Jakarta, Indonesia: Gramedia Pustaka, pp. 101-124, 1995.

[10] A. L. Romanoff and A. J. Romanoff, The Avian Eggs, New York: John Willey and Sons Inc., pp. 123-151, 1963. 
[11] Willson, "The performance of male duckings givens starter diets with different concentration of energy and protein," British Poult Sci., vol. 16 , pp. 625-657, 1975.

[12] Srigandono, The Science of Waterfowl, Yogyakarta, Indonesia: Gadjah Mada University Press, pp. 28-35, 1991.

[13] H. Sugino, T. Nitoda, and L. R. Juneja, "General Chemical Compotition of Hen Egg," Hen Egg, Their Basic and Applied Science, Takehiko, Ed., New York: CRC Press, pp. 35-41, 1997.

[14] H. R. Anggorodi, Poultry Nutrition, Jakarta, Gramedia Pustaka Utama, pp. 35-41, 1995.

[15] K. Sinaga, "The effectiveness of kalinadra flour and cassava leaves in increasing densities of Cirebon duck egg yolk," M. S. thesis, Bogor Agricultural University, Bogor, Indonesia, pp. 41-43, 2006.

[16] Roesdiyanto, "The quality of tegal ducks eggs preserved intensively with multiple levels combination metionin-lancang in feed," $J$ Animal Production, vol. 4, no. 2, pp. 77-82, 2002.

[17] M. J. Stadelman and O. J. Cotterill, Egg Science and Tecnology, 4 th ed., Westport, Conecticut: The AVI Publishing Co. Inc., pp. 230-261, 1995.

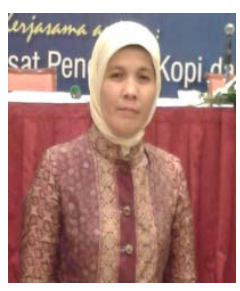

Sofia Sandi was born at Jambi, 23 November 1970 She has got her bachelor degree from Jambi University, South Sumatra Indonesia, on 1995 In 2003, she has got her master degree from Bogor Agriculture Institute (IPB), West Java Indonesia. She got her Doctoral degree also from Bogor Agriculture Institute (IPB), West Java Indonesia in 2010. She is a lecturer at Nutrition and Animal Feed Department, Sriwijaya University (UNSRI). She had been presented and published her researches result in several Journal such as: 1).The nutrient quality of cassava by addition of cow rumen fluid enzyme, which was published at Journal Agriculture Science and Techology 2).Quality of Silage Nutrition Which Had been Given Enzyme from Cow Rumen and Leuconostoc mesentreroides, and was published at Animal Science Journal.

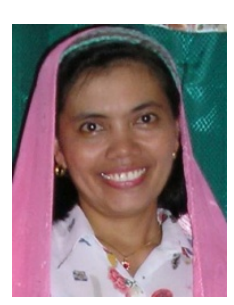

Miksusanti was born at Bengkalis, Riau, middle Sumatra on 23 July 1968. She has got her bachelor degree from Chemistry department Andalas University (UNAND), West Sumatra Indonesia, on 1991. In 1995 she got her master degree on Chemistry from Institute Technology of Bandung (ITB), West Java Indonesia. She has got her doctor degree in Food Science on 2009 from Bogor Agriculture Institute (IPB), West Java Indonesia. She is a lecturer at Chemistry Department, Sriwijaya University (UNSRI). She is co worker in biochemistry laboratory at Chemistry Department Faculty of Mathematic and Natural Science UNSRI. She had presented and published her researches result in several seminars and journals e.i 1. Mode of Action Temu Kunci Essential Oil on E. coli K1.1 Cell determined by Leakge of Material Cell and Salt Tolerance Assays, Hayati Journal Bioscience ,( IPB 2009); 2. Lymphocyte Proliferation by Temu lawak (Curcuma xanthorrhiza ROXB) Essential Oil, Proceeding of, International Seminar on Chemical, Biological and Environmental engineering, Singapore 2012; 3. Antibacterial and Antioxidant of Kaemferia pandurata Essential Oil and It's Application to Make Antibacterial and Antioxidant Edible Film From Sago Starch, Proceeding National Conference of Essential Oil IV, 2010 Bandung Indonesia. Now She is doing several researchs about antibacterial antioxidant edible film and other food safety and liquid food product researches. 